\title{
Podridão-mole em pós-colheita de batata (Solanum tuberosum) incitada por Pseudomonas viridiflava
}

\author{
Dirceu Macagnan $^{1,2}$, Reginaldo da Silva Romeiro ${ }^{1,2}$, Davi Mesquita de Macedo ${ }^{1,3}$; Daniel Augusto Schurt ${ }^{1,3}$
}

\author{
${ }^{1}$ Universidade Federal de Viçosa, Departamento de Fitopatologia CEP 36571-000 Viçosa, MG. e-mail rromeiro@ufv.br ²Bolsistas do CNPq; \\ ${ }^{3}$ Bolsistas CAPES \\ Autor de correspondência: Reginaldo da Silva Romeiro \\ Data de chegada: 07/10/2005 Aceito para publicação em: 08/11/2006
}

\section{RESUMO}

Macagnan, D.; Romeiro, R.S.; Macedo, D.M.; Schurt, D.A. Podridão-mole em pós-colheita de batata (Solanum tuberosum) incitada por Pseudomonas viridiflava. Summa Phytopathologica, v.33, n.3, p.307-308, 2007.

Isolou-se uma bactéria incitadora de podridão-mole em batata e procurou-se identificá-la em nível de espécie. Testes biológicos, bioquímicos e tintoriais permitiram posicionar o microrganismo em questão com pertencente à espécie Pseudomonas viridiflava. Procurou- se também investigar a suscetibilidade de diferentes órgãos de reserva de distintas espécies botânicas à espécie bacteriana. Este trabalho mostra e confirma que outras espécies que não as de Pectobacterium spp. são capazes de incitar podridões-moles em órgãos de reserva

Palavras-chave adicionais: Nova doença, Fitobacteriose, Identificação, Podridão mole

\section{ABSTRACT}

Macagnan, D.; Romeiro, R.S.; Macedo, D.M.; Schurt, D.A.. Post hervest soft rot in potabo (Solanum tuberosum) induced by Pseudomonas viridiflava. Summa Phytopathologica, v.33, n.3, p.307-308, 2007.

A soft rot inducing bacterium was isolated from decaying potato tubers and attempts were made to identify it at species level. Biochemical, biological and staining procedures allowed to identify it as belonging to the species Pseudomonas viridiflava. Additionally, the potential pathogenicity and host range of the identified isolate was checked by artificial inoculation of storage organs of different plants. This paper showed and confirmed that phytobacteria other than Pectobacterium spp are able to induce soft rot and that this fact deserves further investigation as far as crop losses due to prokaryotes are concerned.

Additional Keywords: New disease, Bacterial Disease, Identification, Soft Rot

Podridões-moles em tubérculos de batata (Fig. 1A) são quase sempre atribuídas a espécies do gênero Pectobacterium spp., muitas vezes sem um procedimento de diagnóstico mais elaborado, para confirmação da real etiologia da enfermidade. Podridões-moles são doenças bastante severas, no campo como na pós-colheita, podendo ser incitadas por fungos e por bactérias (1). Quando de etiologia bacteriana, após uma diagnose rápida e visual apenas há uma tendência em se atribuir a causa a algum gênero de Pectobacterium spp., notadamente a $P$. carotovorum subsp. carotovorum, $P$. carotovorum subsp. atrosepticum ou Dicheya chrysanthemi. De fato, a maioria das podridões-moles que são diagnosticadas de forma correta geralmente é causada por Pectobacterium spp. Contudo, muitas vezes podridõesmoles são causadas por espécies de Pseudomonas.

Tubérculos de batata (Solanum tuberosum) com sintomas típicos de podridão-mole coletados em estabelecimentos comerciais da cidade de Viçosa, MG, foram efetuados isolamentos pelo método indireto, utilizando-se como iscas biológicas, escamas de cebola e secções de frutos verdes de pimentão, conforme preconizado por Romeiro (8). O isolamento a partir das iscas foi realizado pelo método padrão para fitobactérias, como descrito por Kado (6). Colônias bacterianas individualizadas foram transferidas para tubos e sua patogenicidade testada utilizando-se o teste de produção de enzimas pectolíticas, descrito por Kado (6). Para tanto secções de tubérculos sadios depositados em placas de Petri foram inoculados tocando-se a cultura com alça de repicagem e, a seguir, a superfície do tecido. Após incubação a $28{ }^{\circ} \mathrm{C}$ por $24 \mathrm{~h}$, aqueles exibindo maceração de tecido no sítio de inoculação (Fig. 1B e1C) foram considerados positivas para o sintoma de podridão-mole. Os isolados que induziram esses sintomas foram submetidos a testes preconizados por Schaad (10) para a sua identificação a nível de gênero. As células bactérianas mostraram-se Gram-negativas em forma de bastonetes, desprovidas de endósporos, pleomorfismo e inclusões de poli ß hidroxibutirato. O microrganismo mostrou-se não produtor de xantomonadina e de colônias amarelas ou alaranjadas em meio YDC ou NBY, assim como não apresentou colônias mucoides a $30^{\circ} \mathrm{C}$ em meio YDC. Colônias da bactéria produziram pigmento fluorescente sob luz UV (366 nm), aeróbica estrita e de crescimento rápido. Apresentou resultados negativos para urease e crescimento a $40{ }^{\circ} \mathrm{C}$. Essas características permitiram posicionar os isolados como pertencentes ao gênero Pseudomonas. A identificação a nível de espécie foi feita conforme recomendações de Braun-Kiewnick \& Sands (4). Segundo estes autores, as únicas espécies de Pseudomonas com atividade pectinolítica são a $P$. marginalis e $P$. viridiflava. Assim 


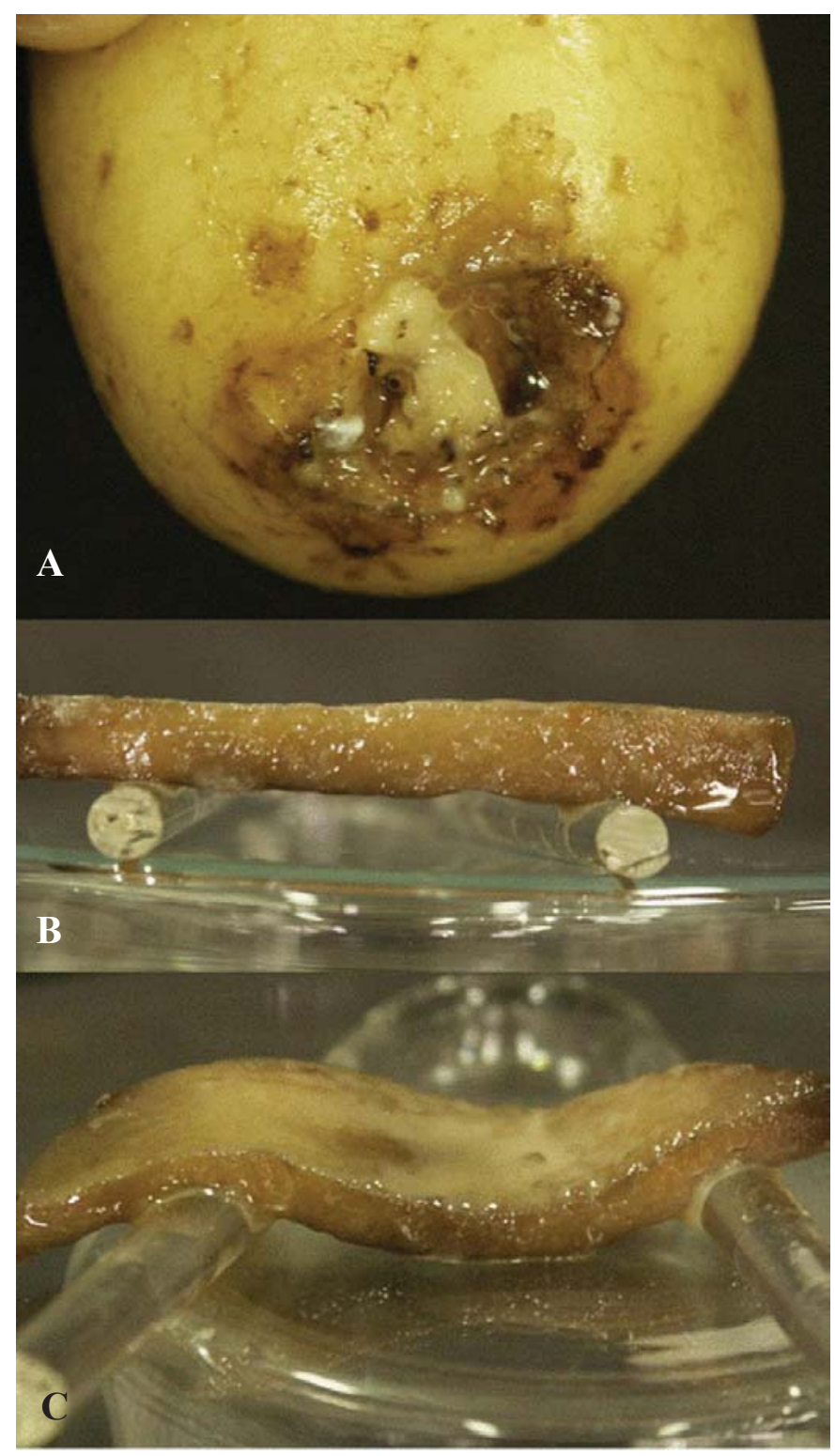

Figura 1. Podridão-mole em batata. Sintomas observados originalmente (A). Resultado de teste de patogenicidade negativo (B) e positivo (C).

sendo procederam-se os testes fisiológicos bioquímicos e tintoriais necessários para o posicionamento do microrganismo em questão em uma das duas espécies. O microrganismo demonstrou ser levam negativo e positivo para desidrolase arginínica. Não incitou reação de hipersensibilidade em fumo e não produziu ácido a partir de trealose e sacarose. Com esses resultados foi possível identificar a bactéria como sendo Pseudomonas viridiflava.

Este isolado foi inoculado por picada (palito dental de madeira) com suspensão do patógeno em diferentes frutos e órgãos de reserva. Observou-se que o isolado bacteriano foi capaz de causar sintomas típicos de podridão-mole em inhame (Calocasia esculenta), batata-doce (Ipomea batatas), abóbora (Curcubita máxima) e chuchu (Sechium edule).

Não foram observados sintomas de podridão em jiló (Solanum gilo), maçã (Malis domestica), tomate (Lycopersicon esculentum), manga (Mangifera indica L.), maracujá (Passiflora edulis), banana (Musa X paradisíaca L.), berinjela (Solanum melongena), beterraba (Beta vulgaris), goiaba (Psidium guajava), abobrinha (Cucurbita pepo), pepino (Cucumis sativus), pimentão (Capsicum annuum), mandioca (Manihot esculentum), batata-baroa (Arracacia xanthorriza), cenoura (Daucus carota), feijão-vagem (Phaseolus vulgaris), cebola (Allium cepa), kiwi (Actinidia deliciosa), maxixe (Cucumis anguria), quiabo (Abelmoschus esculentus) e mamão (Carica papaya).

Vale ressaltar que observou-se intensa fluorescência, ainda que não houvesse apodrecimento ou maceração de tecido em batata-baroa, cenoura, feijão-vagem, cebola, kiwi, maxixe, quiabo e mamão. É possível que o patógeno - uma espécie reconhecidamente polífaga (3) - ainda que não consiga incitar sintomas de podridão-mole nesses hospedeiros, seja capaz de exercer algum tipo de vida saprofítica e, ou, epifítica, a partir de substâncias disponíveis nos tecidos em quantidade suficiente, inclusive, para que aconteça a síntese de pioverdinas.

Há uma multiplicidade de relatos de podridões-moles em plantas incitadas por espécies de Pseudomonas, a exemplo dos relatados em alface, alho, batata, brócolis, cebola, cenoura, chicória, frutos de tomateiro e orquídea $(3,9)$. No Brasil, até o momento há registros de Pseudomonas viridiflava ocorrendo em alface, mandioca, cebola, tomateiro $(7,9)$ alho (2) e feijoeiro (5). Não há registros da ocorrência de podridão-mole em batata causada por $P$. viridiflava. Este trabalho sugere que sintomas de podridão-mole causados por bactérias nem sempre podem ser atribuídos a aquelas pertencentes aos gêneros Pectobcterium spp. e Dickeya spp., e o significado deste fato, em termos de perdas na produção, quer em campo quer na pós-colheita, precisa ser melhor avaliado.

\section{REFERÊNCIAS BIBLIOGRÁFICAS}

1. Agrios, G.N. Plant pathology.: 5.ed. San Diego: Elsevier, 2005 $922 \mathrm{p}$.

2. Beriam, L.O.S.; Malavolta Junior, V.A.; Almeida, I.M.G.; Becker, W.F. Crestamento bacteriano do alho: nova doença causada por Pseudomonas viridiflava no Brasil. Summa Phytopathologica, Botucatu, v.31, Supl, p.94-5, 2005.

3. Bradbury, J.F. Guide to plant pathogenic bacteria. Surrey: C.A.B., 1986. 332p.

4. Braun-Kiewnick, A.; Sands, D.C. Gram-negative bacteria: Pseudomonas. In: Schaad, N.W., Jones, J.B., Chun, W. Laboratory guide for identification of plant pathogenic bacteria. 3.ed. St. Paul. The American Phytopathological Society, 2001. p.84-120.

5. Carrer Filho, R.; Romeiro, R.S.; Vieira, R.F.; Garcia, F.A.O.; Silva, H.S.A.; Pereira, J.L.A.; Batista, U.G. Ocorrência da mancha foliar bacteriana do feijoeiro (Phaseolus vulgaris L.) causado por Pseudomonas viridiflava no Estado de Minas Gerais. Fitopatologia Brasileira, Fortaleza, v.26, Supl., p.296, 2001.

6. Kado, C.I. Methods in plant bacteriology. Davis: Department of Plant Pathology, University of California-Davis, 1977. 86p.

7. Marques, A.S.A.; Robbs, C.F.; Boiteux, L.S.; Parente, P.M.G. Índice de bacterioses assinaladas no Brasil: Brasília, DF: EMBRAPA, 1994. 65p.

8. Romeiro, R.S. Métodos em bacteriologia de plantas: Viçosa: Editora UFV, 2001. 279p.

9. Romeiro, R.S. Bactérias fitopatogênicas: 2.ed. Viçosa: Editora UFV, 2005. 417p.

10. Schaad, N.W. Initial identification of common genera. In: Schaad, N.W.; Jones, J.B.; Chun, W. Laboratory guide for identification of plant pathogenic bacteria. 3.ed. St. Paul: The American Phytopathological Society, 2001.p.1-16. 